\title{
Demonstrating the importance of criteria and sub-criteria in building assessment methods
}

\author{
R. Banani, M. Vahdati \& A. Elmualim \\ School of Construction Management and Engineering, \\ University of Reading, UK
}

\begin{abstract}
Building assessment methods have become a popular research field since the early 1990s. An international tool which allows the assessment of buildings in all regions, taking into account differences in climates, topographies and cultures does not yet exist. This paper aims to demonstrate the importance of criteria and sub-criteria in developing a new potential building assessment method for Saudi Arabia. Recently, the awareness of sustainability has been increasing in developing countries due to high energy consumption, pollution and high carbon foot print. There is no debate that assessment criteria have an important role to identify the tool's orientation. However, various aspects influence the criteria and sub-criteria of assessment tools such as environment, economic, social and cultural to mention but a few. The author provides an investigation on the most popular and globally used schemes: BREEAM, LEED, Green Star, CASBEE and Estidama in order to identify the effectiveness of the different aspects of the assessment criteria and the impacts of these criteria on the assessment results; that will provide a solid foundation to develop an effective sustainable assessment method for buildings in Saudi Arabia. Initial results of the investigation suggest that each country needs to develop its own assessment method in order to achieve desired results, while focusing upon the indigenous environmental, economic, social and cultural conditions.

Keywords: assessment methods, BREEAM, LEED, Green Star, CASBEE, Estidama, sustainability, sustainable buildings, environment, Saudi Arabia.
\end{abstract}

\section{Introduction}

The impact of the construction sector on the environment has been well documented. Since 1990s and upward a great number of rating tools have been 
developed as suggesting efficient solution to assess the effect of construction on the environment. Recently, a number of assessment methods have been developed in different developing countries such as Malaysia, Jordon and United Arab Emirates (UAE) cater to local conditions and practices [1, 2].This is an evidence of awareness rose about sustainability and its benefits in developing countries.

The most commonly used assessment methods are BREEAM (Building Research Establishment's Environmental Assessment Method), developed in UK in 1990s, and LEED (Leadership in Energy and Environmental Design) developed in the USA in 1998. However, Green Star in Australia, CASBEE (Comprehensive Assessment System for Building Environmental Efficiency) in Japan and Estidama in UAE have subsequently emerged.

A number of environmental factors could prevent the direct use of currently available tools in another country other than its own origin [3, 4]. Some of such factors are (1) Climate context, (2) Geographical Features, (3) Resources consumption, (4) Understanding of building stocks, (5) Government policy and regulation, (6) Understanding of the importance of historical features, (7) Understanding of the cultural value and public awareness. It appears that all these factors vary between regions. Even in one country designing a tool could be a challenge where climate and topography change from one place to another. For example, the research that took place in Jordon by Ali and Al Nsairat [2] concluded that Jordon needs to develop a domestic assessment method considering the differences in its climate and topography.

The Kingdom of Saudi Arabia has witnessed considerable growth since 1973. However, the development of construction sector in the country is influenced by its culture. There has been a notable development in the construction sector in Saudi Arabia. An example of these new developments is King Abdullah City for Atomic and Renewable Energy (KACARE), which is located 30 kilometres from Riyadh with a total Gross Floor Area (GFA) of 22,659,859 square meters. This development includes residential, industrial, commercial, educational, social and cultural areas. The design stage of the development was based on the framework of Sustainable Built Environment Tool (SuBET) to ensure high standards of sustainable urban design.

The application of building assessment tools, therefore, indicates that the awareness of sustainability in Saudi Arabia construction industry has increased recently. However, there is no assessment tool developed which considers the condition of Saudi as a country such as weather, social and culture. Hence, an assessment tool for the efficiency of the application of the concept of sustainability is required.

\section{Reviewing environmental assessment methods}

\subsection{Sustainable buildings rating tools}

To guarantee the quality of sustainable construction, a sustainability rating method is required. A report provided by the Pacific Northwest National 
Laboratory has defined 'Sustainable building rating systems' as ''tools that examine the performance or expected performance of a 'whole building' and translate that examination into an overall assessment that allows for comparison against other buildings", [5]. In addition, according to Ding [6], "As environmental issues become more urgent, more comprehensive building assessment methods are required to assess building performance across a broader range of environmental considerations",

Different tools have unique characteristics associated with their country of origin which could be considered as a barrier to reaching international status [7]. The characteristic concepts, as proved by Darus et al. [1], through applying an international assessment method (GBTool) on a Malaysian case, found such a method to be unsuitable for that country as a great number of adjustments would have to be made. Both studies [1,7] prove that each country should design its own assessment method. Moreover, Reed et al. [7] present a useful work for global comparison of sustainable rating tool in order to find an international tool which could be used on a global level.

\subsubsection{Environment, economic, cultural and social aspects}

There is no doubt that environmental issues have significant importance, but consideration of other aspects of sustainability will deliver successful sustainable assessment tools [8]. Todd et al. [9] found that the considerations of economic, social and cultural aspects are responsible for different types of barriers and opportunities that developing countries could face in designing their own domestic rating methods. Whilst a number of studies $[5,8]$ found that these aspects are required for delivering sustainability successfully. Moreover, Poston et al. [10] mentioned that though a number of assessment tools have shifted their emphasis from green to sustainable buildings, there has been criticism of the dominance of environmental criteria at the expense of the social and economic criteria.

Ali and Al Nsairat [2] present economic and cultural aspects, but link their importance with the local context. It is believed that local context determines the importance of economic, social and cultural aspects as a result of their variation from one country to another. For instance, social and cultural aspects in Arabic countries such as Saudi Arabia play an important role in those countries, while economic aspects are the important ones in developed countries. This example is corroborated by Cole [11] who considers the social and economic aspects as important in developing countries with different aspects holding importance in developed countries. Reed et al. [7] consider economic, social and cultural aspects as unique characteristics that could prevent a tool take-up. It is noticeable that a number of developing countries have started developing their domestic assessment methods to be suitable with their environment, and economic, social, cultural and historical contexts [9]. An example is the assessment tool Estidama [10] which was developed in the UAE.

\subsubsection{Tools criteria}

The prime role for the criteria is to achieve an environmental building assessment method goal which 'provides a comprehensive assessment of the 
environmental characteristics of a building" [6]. Systems criteria and its structure have significant effects on the performance evaluation of an assessment method [11]. This is supported by Ali and Al Nsairat [2] who suggests that the system categories define the external boundaries of a tool which is different from one region to another. Therefore, systems criteria are different from one tool to another as a result of continuous development applied to tools criteria to deliver different market, professionals' and owners' aspirations.

\section{Existing building environmental assessment tools}

\subsection{BREEAM}

BREEAM has a long track record in the United Kingdom. It is considered as the first green buildings assessment method [6]. The main goal of developing the BREEAM method was to "Provide authoritative guidance on ways of minimising the adverse effects of buildings on the global and local environments while promoting a healthy and comfortable indoor environment" [12]. The evaluation of a building takes place in a given time using the BREEAM system, whereby a total score is awarded through adding assessment weighting for each criterion (Table 1). The BREEAM uses a fixed weighting system developed by BRE to provide a means of defining, and ranking the relative impact of environmental issues [13]. Moreover, the different main categories in BREEAM, including the one additional category in BREEAM New Construction 2011, are shown in table 1 [13].

Table 1: $\quad$ The BREEAM assessment method categories and weightings.

\begin{tabular}{|l|c|}
\hline \multicolumn{1}{|c|}{ BREEAM categories } & Weighting \\
\hline Management & $12 \%$ \\
\hline Health and Wellbeing & $15 \%$ \\
\hline Energy & $19 \%$ \\
\hline Transport & $8 \%$ \\
\hline Water & $6 \%$ \\
\hline Materials & $12.5 \%$ \\
\hline Waste & $7.5 \%$ \\
\hline Land Use and Ecology & $10 \%$ \\
\hline Pollution & $10 \%$ \\
\hline & $100 \%$ \\
\hline Innovation (additional) & $10 \%$ \\
\hline
\end{tabular}

The additional category incorporated into the new version allows for an extra $10 \%$ credit towards the improvement of the building's performance and supports a building being awarded a higher final score.

\subsection{LEED}

LEED is an environmental assessment system that was designed and developed by the U. S. Green Buildings Council (USGBC), in order to transform the market for green buildings [14]. It is defined as "a framework for identifying, implementing, and measuring green building and neighbourhood design, construction, operations, and maintenance',[15]. Currently, LEED is the second 
worldwide most used building assessment method [16]. However, almost all the studies agree that BREEAM and LEED can be considered as the foundation for most assessment rating tools around the world [7].

To achieve LEED-NC2009 a building is awarded a total score using a point system for each criterion (Table 2). In fact, the assessment considers all various parameters through different categories which are included in LEED (as shown in Table 2) [15].

Table 2: $\quad$ The LEED categories and points distribution.

\begin{tabular}{|l|c|}
\hline \multicolumn{1}{|c|}{ LEED Categories } & Possible Points \\
\hline Sustainable Site & 26 \\
\hline Water efficiency & 10 \\
\hline Energy and atmosphere & 35 \\
\hline Materials and Resources & 14 \\
\hline Indoor Environment Quality & 15 \\
\hline & 100 \\
\hline Innovation and design process & 6 \\
\hline Regional Priority Credit & 4 \\
\hline
\end{tabular}

It can be seen that the LEED categories concentrate on a building's performance relating to environmental sources such as water, energy and materials. As a result, LEED is used not just in the USA, but also in Canada, Spain, China and India [8].

\subsection{Green Star}

Green Star is an Australian environmental rating system launched in 2003 which was developed by the Green Building Council Australia [17]. The assessment tool was originally developed to accommodate buildings' requirements in hot climates, where cooling systems and solar shading are considered as being of fundamental importance [17]. The council designed the tool to deliver the needs of the environment and the people in their buildings through different purposes: to reduce the impact of buildings on the environment (environmental purpose); to enhance the health and productivity of the buildings' users (humanity purpose) and to achieve cost savings (economic purpose) [17]. Green Star is concerned with delivering sustainability in the building sector in a practical way.

Green Star has a credit points system for each criterion that helps buildings be awarded the rating method assessment (Table 3). The assessment points are awarded by examining a building through various categories. The Australian rating method has various categories that cover most aspects of a building as shown in Table 3 [17].

Table 3: $\quad$ Green star categories and credit distribution.

\begin{tabular}{|l|c|}
\hline \multicolumn{1}{|c|}{ Green Star Categories } & Possible Points \\
\hline Management & 12 \\
\hline Indoor Environment Quality & 27 \\
\hline Energy & 29 \\
\hline Transportation & 11 \\
\hline Water & 12 \\
\hline Materials & 25 \\
\hline Land use and Ecology & 8 \\
\hline Emission & 19 \\
\hline & 143 \\
\hline Innovation & 5 \\
\hline
\end{tabular}




\subsection{CASBEE}

The Japanese Sustainable Building Consortium (JSBC) is the developer of the environmental assessment method CASBEE that evaluates and rates the environmental performance of buildings. It was launched in 2001 and the first assessment tool for office buildings was completed in 2002. In addition, consideration is given to three main principles in the development of tool to gain maximum environmental benefits which are; (1) Comprehensive assessment throughout the life cycle of the building (2) Assessment of Building Environmental 'Built Environment Quality (Q)' and 'Built Environmental Lode (L)', (3) Assessment based on the newly-developed Building Environment Efficiency (BEE) indicator [18].

CASBEE defines Built Environment Quality (Q) as "Evaluates improvement in living amenity for the building users, within the hypothetical enclosed space (the private property)"; Built Environmental Lode $(L)$ defined as "Evaluates negative aspects of environmental impact which go beyond the hypothetical enclosed space to the outside (the public property)" [18].

The classifications are awarded through examining a building under different assessment categories that guarantee the application of the concepts of sustainability in the construction. However, CASBEE has different assessment categories from BREEAM, LEED and Green Star. It has two main categories which are (Q) Building Environmental Quality and Performance and (LR) Reduction of Building Environment Loading. The categories involved include: indoor environment $(\mathrm{Q})$, quality of service $(\mathrm{Q})$, outdoor environment on-site $(\mathrm{Q})$, energy (L), resources and materials (L) and off-site environment (L) [18].

Moreover, BEE is considered as a tool indictor and it is an additional process that a building goes through to be awarded the assessment. It could be defined as the following equation calculation:

$$
B E E=\frac{\mathrm{Q}(\text { Environmental Quality })}{\mathrm{L}(\text { EnvironmentalLoad })}
$$

It appears that all the categories focus strongly on the environmental issues. It could be said that the tool categories are based on a building's life cycle which plays a key role in the assessment method.

\subsection{Estidama}

Estidama is the first environmental assessment method developed in the Middle East especially in the Arabian Gulf countries. It means 'Sustainability' in Arabic and it was developed in 2008 by the Abu Dhabi Urban Planning Council (AUPC) in the UAE. The assessment method has a ratings tool called The Pearl Rating System (PRS) that helps to deliver sustainable development efficiently. The main aim of using PRS is to address the sustainability in a building throughout its entire lifecycle design, construction and operation [19]. In addition, the assessed building can be awarded at least 1 Pearl point which contains a number of required credits for each criterion (Table 4) [19]. 
Table 4: $\quad$ Estidama categories and credit distribution.

\begin{tabular}{|l|c|}
\hline \multicolumn{1}{|c|}{ Estidama categories } & Maximum Credit Points \\
\hline Integrated Development Process & 13 \\
\hline Natural System & 12 \\
\hline Liveable Buildings & 37 \\
\hline Precious Water & 43 \\
\hline Resourceful Energy & 44 \\
\hline Stewarding Materials & 28 \\
\hline Innovation Practice & 3 \\
\hline \multicolumn{2}{|c|}{ Total } \\
\hline
\end{tabular}

\section{Tools comparison overview}

Table 5 highlights the features that distinguish each assessment tool. According to Ding [6] life cycle assessment is linked with building assessment method. It includes different building phases; design, construction, operation and deconstruction. However, design, construction and operation phases are considered in all potential assessment methods (BREEAM, LEED, Green Star, CASBEE and Estidama) as shown in Table 5. CASBEE is the only tool that considers deconstruction stage. This stage plays an important role in building life cycle [3]. Deconstruction stage is not affected the application of the tool because this stage could be add to a tool while developing it regularly. Further, Ding [6] found that the most impact stage to apply a tool is the design stage and it is included in all rating tools.

\subsection{Critical comparison of tools criteria}

\subsubsection{Energy, water, waste and materials}

All assessment method includes an energy category which is a significant criterion (as shown in Tables 1-4). BREEAM and Green Star measure the building Energy performance (BEP) considering the reduction of $\mathrm{CO}_{2}$ emission whilst LEED emphasises upon the reduction of energy cost. CASBEE and Estidama have a different approach to assess BEP by focusing on the improvement percentage on annual energy consumption.

Water, waste and materials are considered as key categories in all five assessment tools. However, due to limited annual rainfall, hot climate, and the great energy embodied to provide potable water through desalination in the UAE, Estidama is the only tool that considers water conservation as priority criteria (Table 4). Moreover, due to its negative impact on human and environment, both waste water and solid water are addressed in all five schemes efficiently.

Materials are important elements in environmental assessment methods due to their impacts on building users and the environment. Comparatively, BREEAM focuses on material types and LEED, CASBEE and Estidama encourage use of locally manufactured materials. In terms of cost consideration, Estidama and Green star assess materials whilst calculating its cost in relation to building construction. 
Table 5: $\quad$ Primary features of BREEAM, LEED, green star, CASBEE and Estidama.

\begin{tabular}{|c|c|c|c|c|c|}
\hline & BREEAM & LEED & Green Star & CASBEE & Estidama \\
\hline $\begin{array}{l}\text { Developer } \\
\text { and Year }\end{array}$ & $\begin{array}{l}\text { the U. K. Building } \\
\text { Research Establishment } \\
\text { (BRE); } 1990\end{array}$ & $\begin{array}{l}\text { the US Green } \\
\text { Buildings } \\
\text { Council } \\
\text { (USGBC); } 1998 \\
\end{array}$ & $\begin{array}{l}\text { Green Building } \\
\text { Council } \\
\text { Australia } \\
\text { (GBCA); } 2002 \\
\end{array}$ & $\begin{array}{l}\text { Japan Sustainable } \\
\text { Building Consortium } \\
\text { (JSBC); } 2001\end{array}$ & $\begin{array}{l}\text { Abu Dhabi Urban } \\
\text { Planning Council } \\
\text { (UPC); } 2008\end{array}$ \\
\hline Building Phases & $\begin{array}{l}\text { Design, Construction and } \\
\text { Operation }\end{array}$ & $\begin{array}{l}\text { Design, } \\
\text { Construction and } \\
\text { Operation }\end{array}$ & $\begin{array}{l}\text { Design, } \\
\text { Construction and } \\
\text { Operation }\end{array}$ & $\begin{array}{l}\text { Design, Construction, } \\
\text { Operation and } \\
\text { Deconstruction }\end{array}$ & $\begin{array}{l}\text { Design, } \\
\text { Construction and } \\
\text { Operation }\end{array}$ \\
\hline Buildings Types & $\begin{array}{l}\text { Offices } \\
\text { Housing } \\
\text { Healthcare } \\
\text { Courts } \\
\text { Industrial Units } \\
\text { Prisons } \\
\text { Retail } \\
\text { Schools } \\
\text { Multi Residential } \\
\text { Schools } \\
\text { Neighbourhood }\end{array}$ & $\begin{array}{l}\text { Offices } \\
\text { Homes } \\
\text { Neighbourhood } \\
\text { Development } \\
\text { Retail } \\
\text { Healthcare } \\
\text { Schools }\end{array}$ & $\begin{array}{l}\text { Education } \\
\text { Healthcare } \\
\text { Industrial } \\
\text { Multi- } \\
\text { Residential } \\
\text { Office } \\
\text { Office Interiors } \\
\text { Retail Centre }\end{array}$ & $\begin{array}{l}\text { Residential } \\
\text { Office } \\
\text { Schools } \\
\text { Retail } \\
\text { Health care } \\
\text { Urban development } \\
\text { Cities }\end{array}$ & $\begin{array}{l}\text { Offices } \\
\text { Retail } \\
\text { Multi-Residential } \\
\text { School }\end{array}$ \\
\hline Scope & $\begin{array}{l}\text { New build } \\
\text { Refurbishment } \\
\text { Existing building }\end{array}$ & $\begin{array}{l}\text { New build } \\
\text { Refurbishment } \\
\text { Existing building }\end{array}$ & $\begin{array}{l}\text { New build } \\
\text { Refurbishment } \\
\text { Existing building }\end{array}$ & $\begin{array}{l}\text { New build } \\
\text { Refurbishment } \\
\text { Existing building }\end{array}$ & $\begin{array}{l}\text { New building } \\
\text { Existing building }\end{array}$ \\
\hline \multirow{5}{*}{ Categories } & \multirow{5}{*}{$\begin{array}{l}\text { Management } \\
\text { Health and Wellbeing } \\
\text { Energy } \\
\text { Transport } \\
\text { Water } \\
\text { Materials } \\
\text { Land Use and Ecology } \\
\text { Waste } \\
\text { Pollution } \\
\text { Innovation } \\
\text { (additional) }\end{array}$} & \multirow{5}{*}{$\begin{array}{l}\text { Sustainable Site } \\
\text { Water Efficiency } \\
\text { Energy and } \\
\text { Atmosphere } \\
\text { Materials and } \\
\text { Resources } \\
\text { Indoor } \\
\text { Environment } \\
\text { Quality } \\
\text { Innovation and } \\
\text { Design Process } \\
\text { Regional Priority } \\
\text { Credits }\end{array}$} & \multirow{5}{*}{$\begin{array}{l}\text { Management } \\
\text { Indoor } \\
\text { Environment } \\
\text { Quality } \\
\text { Energy } \\
\text { Transport } \\
\text { Water } \\
\text { Materials } \\
\text { Land Use and } \\
\text { Ecology } \\
\text { Emissions } \\
\text { Innovation }\end{array}$} & $\begin{array}{l}\text { Environmental } \\
\text { Quality (Q) }\end{array}$ & \multirow{5}{*}{$\begin{array}{l}\text { Integrated } \\
\text { Development } \\
\text { Process } \\
\text { Natural Systems } \\
\text { Liveable Buildings } \\
\text { Precious Water } \\
\text { Resourceful } \\
\text { Energy-Stewarding } \\
\text { Materials } \\
\text { Innovating Practice }\end{array}$} \\
\hline & & & & $\begin{array}{l}\text { Indoor Environment } \\
\text { Quality-of-Service } \\
\text { Outdoor Environment } \\
\text { on site }\end{array}$ & \\
\hline & & & & $\begin{array}{l}\text { Environmental Load } \\
\text { (L) }\end{array}$ & \\
\hline & & & & $\begin{array}{l}\text { Energy } \\
\text { Resources and } \\
\text { Materials } \\
\text { Off-site Environment. }\end{array}$ & \\
\hline & & & & $\begin{array}{l}\text { BEE (Building } \\
\text { Environmental } \\
\text { Efficiency) }=\mathrm{Q} / \mathrm{L}\end{array}$ & \\
\hline Rating & $\begin{array}{c}\text { Pass } \\
\text { Good } \\
\text { Very Good } \\
\text { Excellent } \\
\text { Outstanding } \\
\end{array}$ & $\begin{array}{l}\text { Certified } \\
\text { Silver } \\
\text { Gold } \\
\text { Platinum }\end{array}$ & $\begin{array}{l}1 \text { - } 3 \text { Stars } \\
4 \text { Stars } \\
5 \text { Stars } \\
6 \text { Stars }\end{array}$ & $\begin{array}{c}\text { Poor (c) } \\
\text { Slightly Poor(B-) } \\
\text { Good(B+) } \\
\text { Very Good (A) } \\
\text { Superior (S) } \\
\end{array}$ & $\begin{array}{l}1 \text { Pearl } \\
2 \text { Pearl } \\
3 \text { Pearl } \\
4 \text { Pearl } \\
5 \text { Pearl }\end{array}$ \\
\hline Update process & Annual & As required & Annual & As required & Not available \\
\hline $\begin{array}{c}\text { Number of } \\
\text { certificated } \\
\text { Buildings }\end{array}$ & 7,202 & 2,858 & 78 & 80 & Not available \\
\hline International use & $\begin{array}{c}\text { Canada, Hong Kong and } \\
\text { Netherlands }\end{array}$ & $\begin{array}{c}\begin{array}{c}\text { Emirates, India } \\
\text { and Brazil }\end{array} \\
\end{array}$ & $\begin{array}{c}\text { New Zealand } \\
\text { and South Africa }\end{array}$ & - & - \\
\hline
\end{tabular}

\subsubsection{Indoor environment quality, pollution and management}

The quality of indoor environment is considered as key objective in all building assessment methods. All five schemes cover this category with respect to different elements. BREEAM covers materials category giving importance for ventilation and HVAC systems [13]. At the same time LEED covers this category focusing upon low-emitting materials criteria [20]. Green Star has emphasised on air condition systems and lighting. Whilst, CASBEE covers indoor environment quality well enough under the sub category of indoor quality (Q1) of Built Environment Quality category (Q). It also further supports this category by including most of the parameters from Quality of service category which is also the sub-category (Q2) of the Built Environment Quality. Estidama 
assesses indoor environment quality with more consideration for materials emission and thermal comfort.

Each tool assesses pollutions category using various methods. BREEAM, Green Star and CASBEE are dedicated the issue as an individual category, whilst LEED and Estidama distribute the themes of pollutions across the scoring process. BREEAM evaluates refrigerant issues beside the number of pollutions such as $\mathrm{CO}_{2}$ and NOx emissions. Similarly, Green Star addresses the same problems almost like BREEAM.

In contrast, LEED and CASBEE evaluate Heat island effects criterion while it is overlooked in BREEAM, Green Star and Estidama [20]. Nevertheless, CASBEE considers local environment of Japan and measures parameters which cannot be found in other assessment methods such as Earthquake Resistance and Restriction of Wind Damage [18]. Whilst, Estidama emphasises on refrigerant issues due to the higher demand of air-condition system.

BREEAM and Green Star consider management as a separate category, whilst LEED, CASBEE and Estidama distribute parameters of management across different assessment categories. Green star focuses on commissioning and environmental management, while CASBEE prioritises planning and management of maintenance. Estidama and LEED explicitly address the management of indoor air quality and materials.

\subsubsection{Site, ecology and management}

Site and ecology are the most important categories that relate to building environmental effect directly. All five tools cover almost same criteria of land use and ecology. However, each method applies it differently. BREEAM considers the creation of ecology as the most important criterion, whilst under LEED; site selection is a highly important. Green star pays more attention to the ecological value of site, while CASBEE focuses on the local characteristics of the site, townscape and landscape. Estidama focuses more on natural resource management, sustainable land use and creation and restoration of habitat [20]. What is more, the criteria of Townscape and Landscape, Local Characteristics and Out-door Amenity are not given that much importance in BREEAM, LEED and Green Star, however, they are given considerably much importance in CASBEE and Estidama.

\subsubsection{Economic and social aspects}

Economic aspects contain cost efficiency and quality of services categories. All parameters of cost efficiency are distributed across different assessment categories. BREEAM and Estidama are the only tools which evaluate 'Life cycle costing' parameter under different category. Operation and maintenance costs have been considered in BREEAM, LEED, and Estidama while they are overlooked in Green Star and CASBEE. Indeed, economic issues have been covered in BREEAM, LEED, Green Star and Estidama poorly into their assessment frameworks. Nevertheless, Estidama cover these issues better than the other tools mentioned above.

Quality of service is comprehensively considered only in CASBEE among the five assessment methods. However, BREEAM and Estidama included some 
criteria in their assessment process such as durability and protection and reliability. Estidama distinguishes from BREEAM by considering flexibility and adaptability and systems renewability.

LEED and Green Star, on the other hand, have no criteria that are applicable to this category except system controllability in LEED and flexibility and adaptability in Green Star. Local context of Japan appears in quality of service category in CASBEE in the form of for example earthquake resistance.

Social aspects are in three different categories; innovation, transportation and cultural. BREEAM and LEED both display almost same criteria of innovation [4]. Green Star uses innovation criteria to achieve maximum environmental benefits and fosters the industry's transition to sustainable building [17]. CASBEE has no consideration for innovation criteria due to its evaluation framework.

Estidama has covered innovation category in a unique manner. It achieves the category through embracing it in design with respect to the cultural identity of the region [19]. All five assessment methods covered transportation criteria in their assessment frameworks. However, only BREEAM and Green Star consider transportation as individual category in their assessment frameworks. LEED, CASBEE and Estidama distribute the themes of transportation across the scoring process.

BREEAM considers transportation under Transport category whilst distinguishing travel plan, which is related strongly with accessibility of public transport [16]. LEED includes transportation under Sustainable site category providing more attention to public transportation access and bicycle facilities. Green Star focuses on car parking provision and cyclist facilities with no attention for community facilities.

CASBEE considers transportation with taking more care for community facilities and bicycle facilities. Estidama has no individual category for transportation, hence it covers same criteria under Liveable Buildings category likewise BREEAM. Only CASBEE and Estidama consider culture and tradition significantly while BREEAM, LEED and Green star completely overlook this issue. CASBEE addresses the cultural aspects under 'Outdoor Environment onSite' category whilst Estidama deals with it under 'Innovating Practice' category. Both tools seek to consider environment through cultural and traditional views.

\section{Conclusion}

This study aims to demonstrate the importance of criteria and sub-criteria in building assessment methods. It is clear that all five assessment tools have common criteria and goal such as energy, water and materials for increase the knowledge about the built environment with decreased impacts of the construction on its users and the environment.

The comparison shows that each tool applies these criteria and have goals based on different aspects; environmental, economic, social and cultural. Indeed, the environmental theme is clearly dominated in all five schemes. However, 
economic and social aspects have been considered in indirect way through distributed sub-criteria across different assessment categories such as LEED and Green Star. Cultural aspects have been overlooked in the assessment framework consideration such as in BREEAM, LEED and Green Star. Regional environmental circumstances also play an important role in tool's criteria.

Further, the region's policy and regulation are appeared in all assessment methods except Estidama who linked the assessment with international standards. This interface between criteria and region's policy and regulations influenced the implementation of assessment method and results due to their territorial differences. For instance, BREEAM and LEED both included energy category in their assessment framework however, each tool use different energy assessment method as shown in comparison. This provides a significant difference in results [20].

This study has shown that the categories of assessment methods are interrelated to each other and play an important role in identifying the tool orientation and results. Hence, the ultimate goal of delivering sustainability could not be met unless regional preferences are considered in assessment criteria. It is therefore concluded that developing specific tool's criteria considering environment, economic, social and cultural aspects of Saudi Arabia guarantee delivering sustainable buildings in Saudi Arabia successfully.

\section{References}

[1] Darus, Z. M., Hashim, N. A., Salleh, E., Haw, L. C., Rashid, A. K. A., and Manan, S. N. A., Development of rating system for sustainable building in Malaysia. Proc. of Conf. on WSEAS Transactions on Environment and development, 5(3), pp. 206-272, 2009.

[2] Ali, H. and Al Nsairat, S., Developing a green building assessment tool for developing countries - Case of Jordan. Building and Environment, 44(5), pp. 1053-1064, 2009.

[3] Mao, X., Lu, H. and Li, Q, A Comparison Study of Mainstream Sustainable/Green Building Rating Tools in the World. Proc. Of Conf. in Management and Service Science, MASS '09, IEEEE, pp, 1-5, 2009.

[4] Alyami, S. H. and Rezgui, Y., Sustainable building assessment tool development approach. Sustainable Cities and Society, 5(0), pp, 52-62, 2012.

[5] Fowler, M. and Rauch, M., Sustainable Building Rating Systems Summary. Contract July 2006 for United States Department of Energy, pp. 1-55, 2006.

[6] Ding, G., Sustainable construction - The role of environmental assessment tools. Environmental Management, 86(3), pp. 451-464, 2008.

[7] Reed, R., Bilos, A., Wilkinson, S. and Schulte, K., International comparison of sustainable rating tools. JOSRE, 1(1), pp. 1-22, 2009.

[8] Haapio, A. and Viitaniemi, P., A critical review of building environmental assessment tools. Environmental Impact Assessment Review, 28(7), pp. 469-482, 2008. 
[9] Todd, J., Crawley, D., Geissler, S. and Lindsey, G., Comparative assessment of environmental performance tools and the role of the Green Building Challenge. Building Research and Information, 29(5), pp. 324335, 2001.

[10] Poston, A., Emmanuel, R. and Thomson, C., Developing holistic frameworks for the next generation of sustainability assessment methods for the built environment. Proc. Of the 26th Annual ARCOM Conference, Egbu: Leeds, UK, pp. 1487-1496, 2010.

[11] Cole, R., Building environmental assessment methods: redefining intentions and roles. Building Research and Information, 33(5), pp. 455467, 2005.

[12] Baldwin, R., Yates, A., Howard, N. and Rao, S., BREEAM 98 for offices: an environmental assessment method for office buildings. Construction Research Communication Ltd: London, pp. 1-36, 1998.

[13] Building Research Establishment Ltd (BRE), BREEAM New Construction: Non- Domestic Buildings: Watford, pp. 1-406, 2011.

[14] Sev, A., A comparative analysis of building environmental assessment tools and suggestions for regional adaptations. Civil Engineering and Environmental Systems, 28(3), pp. 231-245, 2011.

[15] U.S. Green Building Council (USGBC), LEED 2009 for New Construction and Major Renovations Rating System With Alternative Compliance Paths For Projects Outside the U.S: Washington, DC, pp. 1-117, 2009.

[16] Sleeuw, M., A comparison of BREEAM and LEED environmental assessment methods, Report, University of East Anglia Estates and Buildings Division: Norwich, pp. 4-11, 2011.

[17] Green Building Council Australia (GBCA). Green Star overview, Online. http://www.gbca.org.au/green-star/green-star-overview.

[18] Japan Sustainable Building Consortium (JSBC). CASBEE, Comprehensive Assessment System for Built Environment Efficiency Technical Manual: Tokyo, pp. 1-307, 2011.

[19] Abu Dhabi Urban Planning Council (AUPC), Pearl Building: Guide for consultant, Estidama, pp. 1-72, 2010.

[20] Kawazu, Y., Shimada, N., Yokoo, N. and Oka, T., Comparison of the assessment results of BREEAM, LEED, GBTool and CASBEE. Proc. of Int. Conf. on the Sustainable Building (SB05): Tokyo, Japan, pp. 17001705, 2005. 